\title{
BASICLADIA CHELONUM (COLLINS) W.E. HOFFMANN ET TILDEN (CHLOROPHYTA, CLADOPHOROPHYCEAE) FROM CUBA (CARIBBEAN): NEW OBSERVATION OF THE ULTRASTRUCTURE OF ITS VEGETATIVE CELLS
}

\author{
Teresa Mrozińska, JoAnna CZerwiK-MarcinKowsKa*, Maria WebB-Janich \\ * Department of Botany, Institute of Biology, \\ University of Jan Kochanowski \\ Świętokrzyska 15, 25-420 Kielce, Poland \\ e-mail: marcinko@kielce.com.pl
}

(Received: October 1, 2008. Accepted: February 25, 2009)

\begin{abstract}
Basicladia chelonum (Collins) W.E. Hoffmann and Tilden (1930) principally known from North America and Hawaii was recently (2004) found in Cuba (Caribbean) from artificial pool growing on shells of musk turtles (Trachemys decussata Gray). Specimens collected in Cuba were subjected to detailed examinations also using a transmission electron microscope. On one hand, these studies confirmed many features of this species previously described by earlier authors in the specimens from Texas. On the other hand, the present studies revealed structures unknown so far (pyrenoid structure), which allowed for new analysis of this species. These investigations also have shown that Basicladia chelonum exhibits close similarity to the genus Cladophora and other representatives of the class Cladophorophyceae. The similarities include : siphonocladous level of organization of thallus, numerous chloroplasts forming a network and other structures. Conversely, the pyrenoid in vegetative cells of Basicladia chelonum distinguishes it markedly from representatives of the genus Cladophora, which have bilenticular pyrenoids divided into two hemispheres by a single thylakoids and each hemisphere is covered by a bowlshaped starch grain (Van Hoek et al. 1995). Since in Cladophora the ultrastructure of the pyrenoid is highly constant and characteristic, this contrasts with the genus Basicladia and, therefore, more firmly establishes position of the latter as an independent unit within Cladophorophyceae.
\end{abstract}

KEY WORDS: green algae, turtles, taxonomy, ultrastructure, Cuba, Caribbean.

\section{INTRODUCTION}

Basicladia chelonum (Collins) W.E. Hoffmann et Tilden (1930) reported from North America and Hawaii. It was described by F.S. Collins (1907) at the beginning as Chaetomorpha chelonum and later transferred by Hoffmann and Tilden (1930) to the new genus Basicladia, is recently also known from Cuba (Caribbean), which presently comprises: Basicladia crassa Hoffmann et Tilden (1930), B. ramulosa Ducker (1958), B. vivipara Normandin et Taft (1959) and the above-mentioned species. The species are characterized by a very distinctive biology, namely, they live in close mutualistic relationship with an animal. In the natural environment they are attached to the carapaces of freshwater turtles and to the shell of a snail (Viviparus malleatus). Hoffmann and Tilden described Basicladia chelonum from shells of snapping turtles (Chelydra serpentina). Edgren and Tiffany (1953) has B. chelonum reported from shells of pointed turtles (Chrysemis picta) and musk turtles (Stenotherus odoratus). Belusz and Reed (1969) by making a large number of observations of the occurrence of Basicladia, mainly on turtles from Michigan they found that it grew much frequently on Chelydra serpentina and Stenotherus odoratus than on the various species of the Emydidae. In Cuba Basicladia chelonum was living on carapaces of turtles Trachemys decussata Gray.

Due to the character of the thallus (of siphonocladous organization) of the genus Basicladia (Bourrelly 1966; Hori et al. 1967) included it in the order Siphonocladiales of the class Ulotrichophyceae, in agreement with the classification used at that time. In Bourrelly book's, this author maintained the genus Basicladia as an independent unit, thereby opposing the concept presented by Van Hoek (1963), who suggested that due to structural similarity to the genus Cladophora, it should be included to this genus. According to the newest taxonomy (Colt et al. 1995; Van Hoek et al. 1995), the genus Basicladia with its characteristic features fits the best in the class Cladophorophyceae of the division Chlorophyta.

Investigation of ultrastructure of vegetative and reproductive cells and their detailed analysis will greatly aid proper solution of the problems, connected with systematic position of the species under examination. 

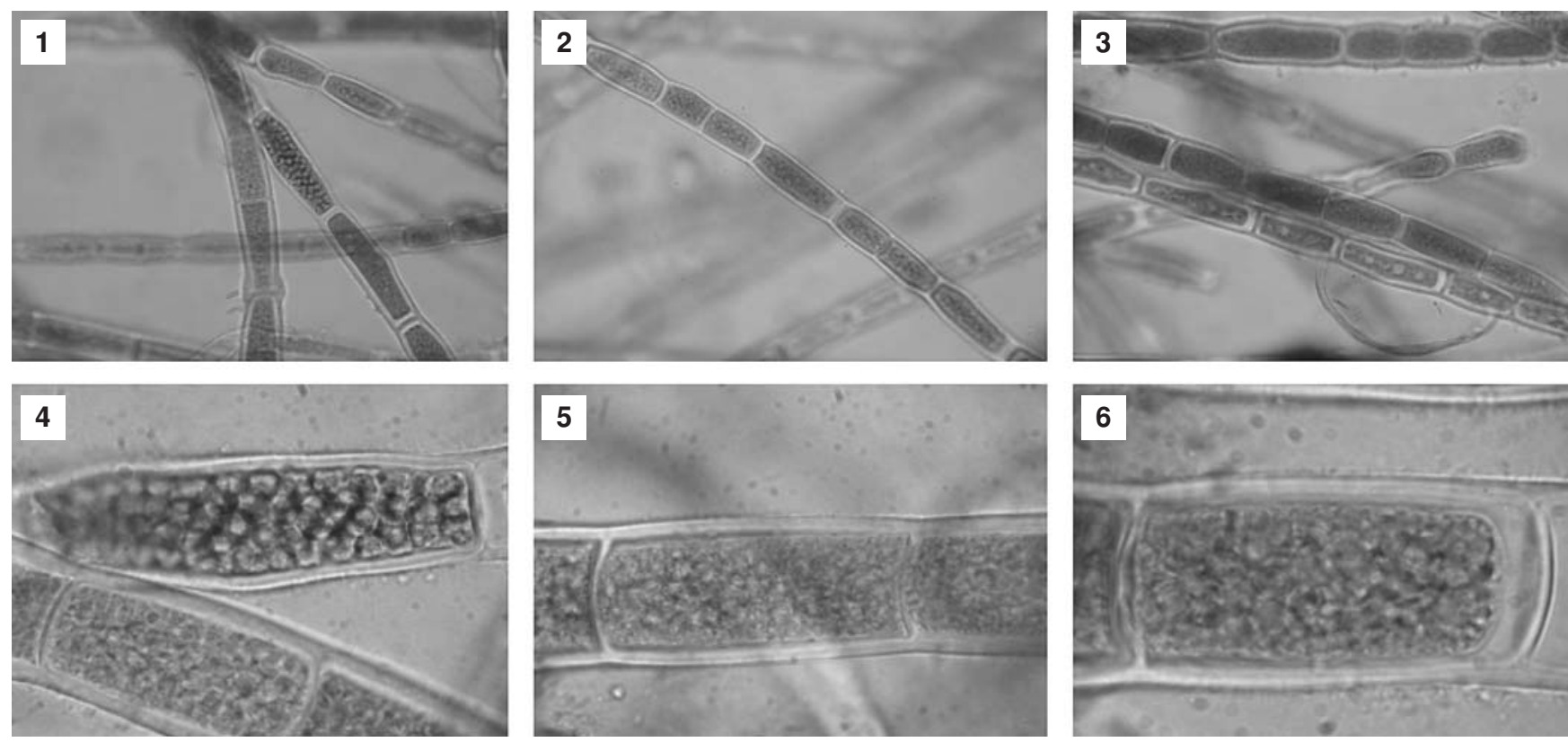

Figs 1-6. Basicladia chelonum. General view of a thallus under light microscopy. (All scale bars represent 10 ěm). Figs 1-3 - vegetative filaments; Figs 1 and 4 - zoosporangium; Figs 5-6 - the wall of some filaments is thickened at the septum and appears H-shaped.
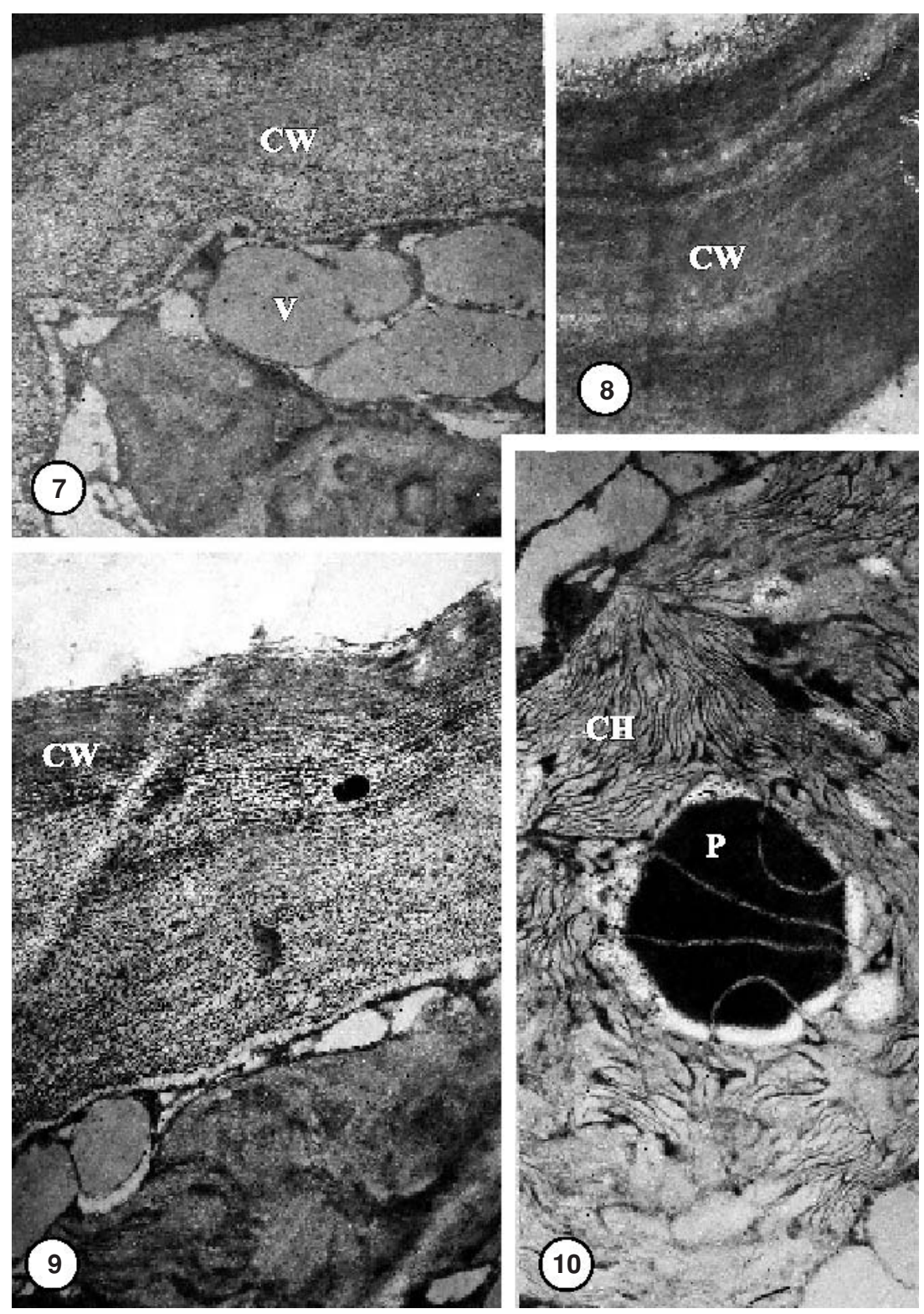

Figs 7-18. Transmission electron microscopy (TEM) of vegetative and reproductive cells of Basicladia chelonum (ch - chloroplast; $\mathrm{t}$ - thylakoids; $\mathrm{n}$ - nucleus; $\mathrm{s}$ - starch grains; $\mathrm{v}$ - vacuole; $\mathrm{p}$ - pyrenoid; $\mathrm{cw}$ - cell wall). Figs 7-9 - cell wall. Figs 10-11 and 17 a cross section of polypyramidal pyrenoid with thylakoids. Fig. 12 - part of vegetative cell with numerous chloroplasts. Fig. 13 - a single polypyramidal pyrenoid; around the pyrenoid there are up to 7 starch grains. Figs 14-16 and 18 - a single nucleus close to chloroplast. Fig. 15 - fragment of undulated double layered cell wall. 

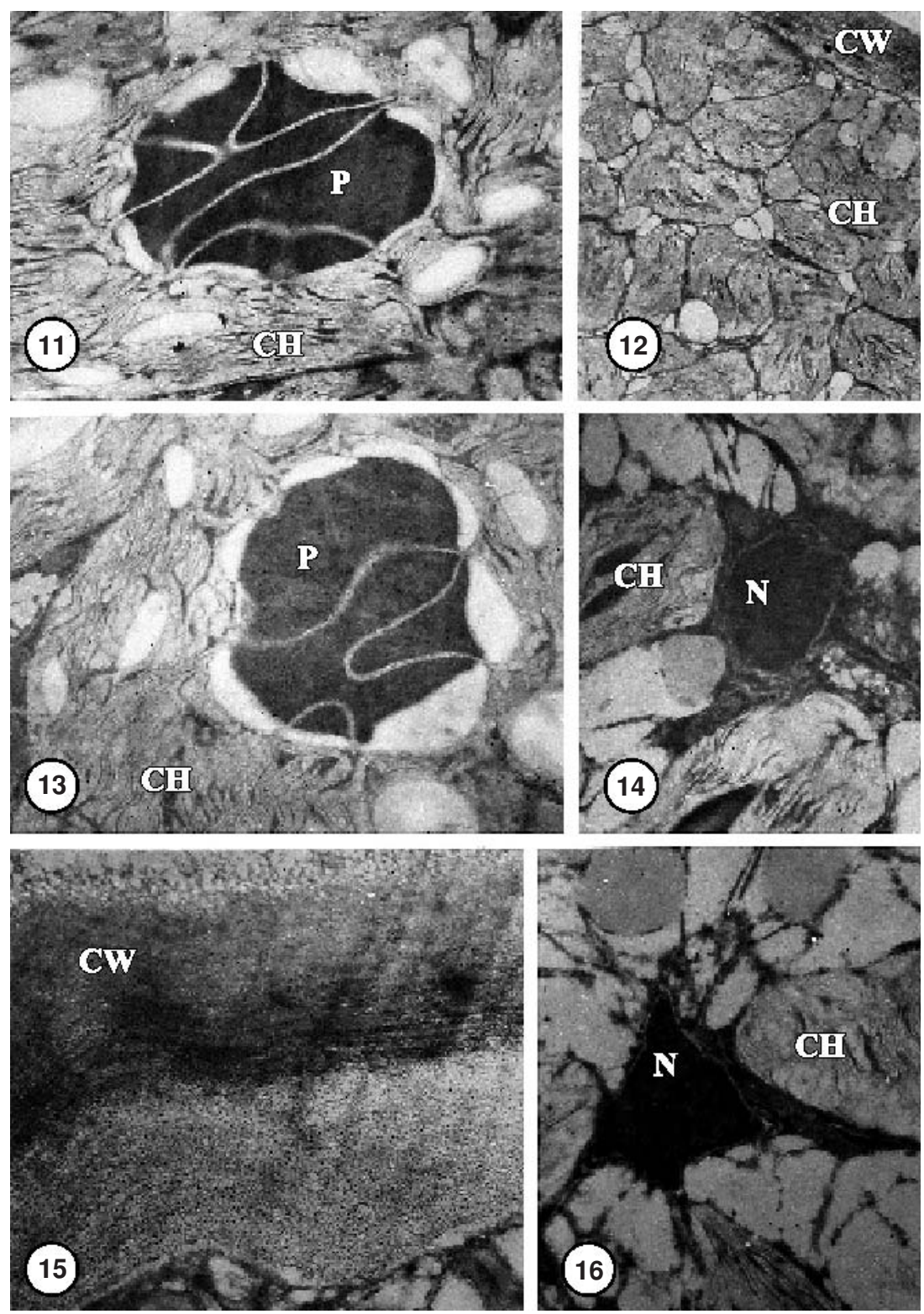

Figs 7-18. Cont.

\section{MATERIAL AND METHODS}

Study material derives from a freshwater turtle (Trachemys decussata) living in a pool belonging to a small roadside shopping and restaurant center along the road between Santa Clara and Varadera (Cuba). The material collected from the surface of the turtle carapaces was subjected to detailed studies also using light and electron microscope.

One part of the investigated materials was directly examined in light microscope and the other part was introduced into cultures at the laboratory. Cultures were maintained on the standart Bristol agar medium at $20^{\circ} \mathrm{C}$ under a $16 / 8 \mathrm{~h}$ light/dark cycle at $3000 \mu \mathrm{Em}^{-2} \mathrm{~s}^{-1}$ provided by 40 $\mathrm{W}$ cool fluorescent tubes. Cells were fixed and processed for transmission electron microscopy as previously described (Massalski et al. 1995). Observations and photographs were made with a TESLA BS 500 electron microscope.

The identification of material was based on the following literature: Hutchinson (1975), Starmach (1972), Van Hoek (1963), Van Hoek et al. (1995).
RESULTS

It is the first report of Basicladia chelonum (Collins) W.E. Hoffmann et Tilden from Cuba (Caribbean). It was growing on carapaces of turtles (Trachemys decussata). Its threads like in the specimen from Texas are usually single, unbranched, sometimes twisted. At the base of upstright threads, a side branch is formed. Rhizoids at the basal part are usually round and they attach to the turtle shell. Further cells of the thread are oblong and shortened at the top. Vegetative cells are 33-40-50 $\mu \mathrm{m}$ broad, 47-120 (-200 $\mu \mathrm{m})$ long. Cell wall of vegetative cells $(3-6-7.3 \mu \mathrm{m})$ is thick and layered. Rhizoids at the base of the thalus are 12-20 $\mu \mathrm{m}$ broad and up to $800 \mu \mathrm{m}$ long (Figs 1 and 4).

Thalli of this algae have a siphonocladous level of organization, i.e. the filament is composed of multinucleate cells. Numerous nuclei occur in cytoplasm outside of the chloroplast. Vegetative cells contain numerous irregular chloroplasts, which form a parietal network. The chloroplasts may also extend into the cell along the cytoplasmic strands that traverse the vacuole. In some chloroplasts, there is a single polypyramidal pyrenoid with thylakoids pene- 

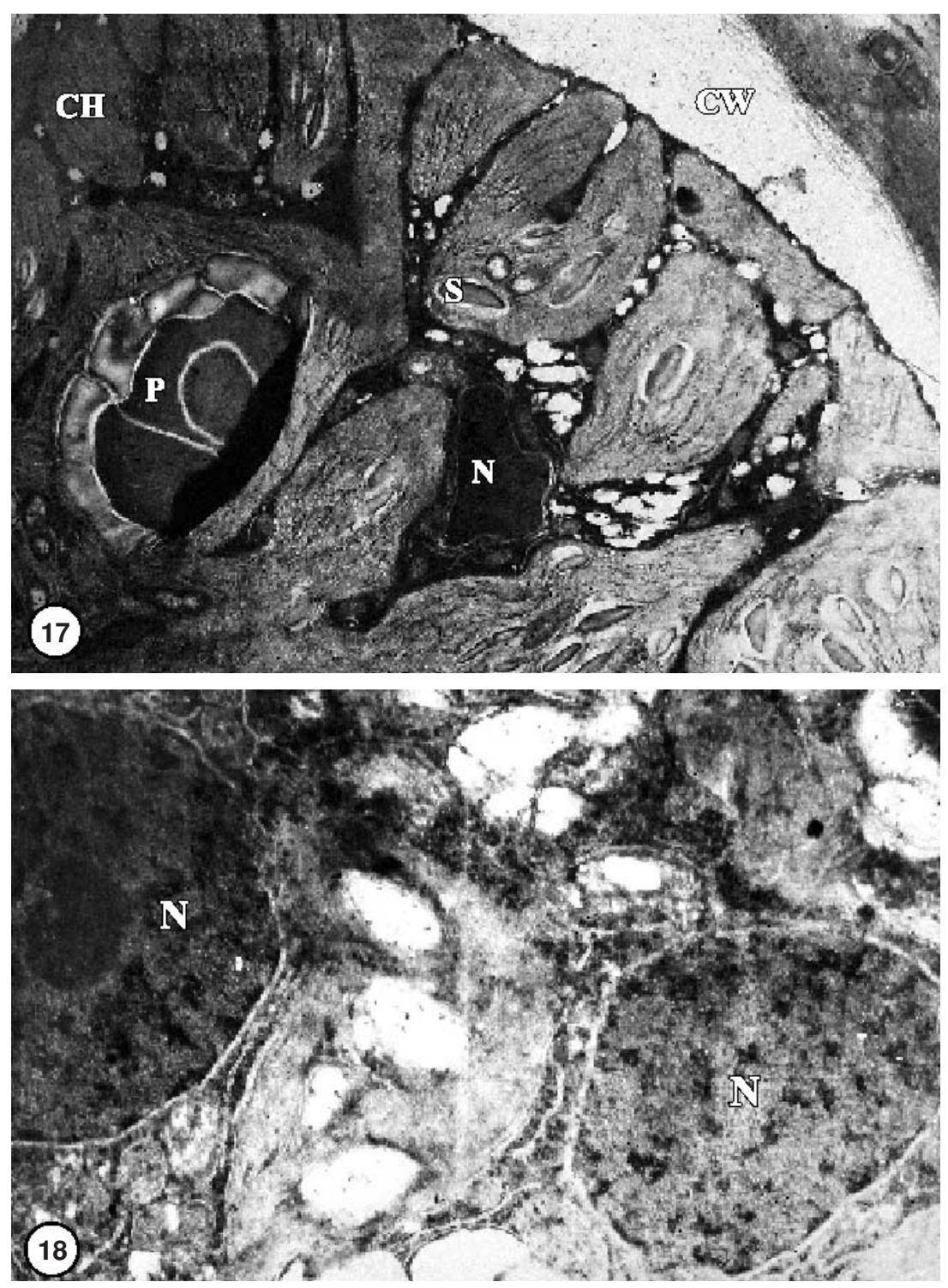

Figs 7-18. Cont.

trating not only outside but also the pyrenoid stroma. Around the pyrenoid, there are up to 7 starch grains.

Basicladia chelonum from Cuba reproduces similarly as specimens from Texas, by zoospores 7-8 $\mu \mathrm{m}$ broad, 13.5$-14 \mu \mathrm{m}$ long, with two flagella, formed in intercalary zoosporangia 37-40 $\mu \mathrm{m}$ broad and 51-98 $\mu \mathrm{m}$ long. Zoospores get outside of zoosporangium through lateral opening in its wall (Figs 1 and 4). A zoospore contains one chloroplast with a single pyrenoid surrounded by 1 starch grain or by 2 bowl-shaped starch grains.

The present studies showed that the Basicladia chelonum exhibited great similarity to the genus Cladophora and other representatives of the class Cladophorophyceae, due to siphonocladous organization of their thallus, reticular chloroplast and other structures. However, some other features distinguished them from Cladophorophyceae representatives, particularly from Cladophora. The main difference was a structure of pyrenoid, situated on the chloroplast in vegetative cells. The pyrenoid, which rather rarely occurs on a chloroplast of a vegetative cell, had polypyramidal structure. Only a pyrenoid occurring on a chloroplast in a zoospore is sometimes similar to the pyrenoid on the chloroplast in the genus Cladophora (Figs 8-19).
Further detailed studies of ultrastructure of vegetative and reproductive cells in this species can bring new data and can even more firmly establish taxonomic position of this species within the class Cladophorophyceae.

\section{ACKNOWLEDGEMENTS}

The authors would like to express their gratefulness to Mgr Krystyna Świeca (Department of Botany, Institute of Biology, Świętokrzyska Academy in Kielce) for excellent technical assistance. Sincere thanks are due to Prof. Zygmunt Szyndlar (Institute of Systematic and Evolution of Animals of PAN) for determination taxonomy of turtles.

\section{LITERATURE CITED}

BELUSZ L.C., REED R.J. 1969. Some epizoophytes on sixe turtle species collected in Massachusetts and Michigan. Amer. Midland Naturalist. 81: 598-601.

BOURRELLY P. 1966. Les algues d'eau douce. 1. Les algues vertes. Paris, Ed Boubee. 
CHAN K.Y., WONG S.L.L. 1978. Observations on Chaetomorpha brachygona Harv. (Chlorophyta, Cladophorales). Ultrastructure of vegetative cells. Phycologia 17: 419-29.

COLT L.C. JR., SAUMURE R.A. JR., BASKINGER S. 1995. First record of the algal genus Basicladia (Chlorophyta, Cladophorales) in Canada. Canadian Field-Naturalist 109: 454-455.

COLLINS F.J. 1907. Some new green algae. Rhodora 2: 197-202.

DUCKER S.C. 1958. A new species of Basicladia on Australian freshwater turtles. Hydrobiologia 10: 157-174.

HOFFMANN W.E., TILDEN J.E. 1930. Basicladia a new genus of Cladophoraceae. Bot. Gaz. 89:374-384.

HORI T., UEDA R. 1967. Electron microscope studies on the fine structure of plastids in siphonous green algae with special reference to their phylogenetic relationships. Sci. Rep. Toyo Daigaku. Sect. Bot. 12: 225-44.

HUTCHINSON G.E. 1975. A treatise on limnology vol. 3. Limnological botany: 562-564 John Wiley \& Sons, New York.
MASSALSKI A., MROZIŃSKA T., OLECH M. 1995. Lobococcus irregularis (Boye-Pet.) Reisigl var. nov. (Chlorellales, Chlorophyta) from King George Island, South Shetland Islands, Antarctica, and its ultrastructure. Nova Hedwigia 61 (1-2): 199-206.

NORMANDIN R.F., TAFT C.R. 1959. A new species of Basicladia from the snail Vivipara malleatus Reeve. Ohio J. Sci. 59: 58-62.

STARMACH K. 1972. Chlorophyta III. (Filamentous Green Algae). Zielenice Nitkowate: Ulotrichales, Ulvales, Prasiolales, Sphaeropleales, Cladophorales, Chaetophorales, Trentepohliales, Siphonales, Dichotomosiphonales. (Freshwater flora of Poland). Flora Słodkowodna Polski 10. In: Starmach K. (ed.): PWN, Warszawa-Kraków. 750. (in Polish)

VAN HOEK C. 1963. Revision of the European species of Cladophora E. J. Brill. Leiden.

VAN HOEK C., MANN D.G., JAHNS H.M. 1995. Algae. An introduction to phycology. Cambridge, University Press: 623. 